\title{
Forum
}

\section{Standardized Ecological Classification for Mesoscale Mapping in the Southwestern United States}

\author{
Patrick J. Comer ${ }^{1}$ and Keith A. Schulz ${ }^{2}$ \\ Authors are ${ }^{1}$ Chief Terrestrial Ecologist and ${ }^{2}$ Regional Vegetation Ecologist, NatureServe, 4001 Discovery Drive, Suite 2110 , Boulder, CO 80303.
}

\begin{abstract}
Standardized ecological classification units form the foundation for effective data collection, assessment, and reporting on ecosystems. Attempts at regional land cover mapping often falter on this point or struggle along inefficiently. Over the past decade, NatureServe has worked with the Gap Analysis Program and others to map existing vegetation using the US National Vegetation Classification (US-NVC). US-NVC is a system of hierarchical structure and rules that are designed to provide a national classification of existing vegetation. Experience has demonstrated the need to develop map units at conceptual scales intermediate between the narrowly specific alliance (floristic) and the broadly generalized formation (physiognomic) levels of the US-NVC. NatureServe defined over 630 "mesoscale" vegetation-based units that are described across the lower 48 United States. These mesoscale classification units, which we term "terrestrial ecological systems," are described using multiple plant communities that tend to co-occur based on recurrent similarities in environmental setting and ecological dynamics. By integrating environmental setting and ecological processes with vegetation into the concept of each unit, this classification system lends itself to biophysical modeling and robust characterization of wildlife habitat. These units apply well to land cover mapping and may be augmented with modifiers for specific variants in composition and structure resulting in robust, standardized maps. Regional-scale mapping of "near-natural" land cover was completed by the Southwest Regional Gap Analysis Project using 109 ecological system units, currently the most detailed regional land cover map of its kind. Terrestrial ecological system units provide a direct, systematic link to the US National Vegetation Classification and may also provide a useful framework for integration with ecological site concepts and descriptions.
\end{abstract}

\section{Resumen}

Clasificaciones ecológicas forman la fundación para la recolección de datos, evaluación, y reportaje sobre el estado de los ecosistemas. Por falta de clasificaciones adecuadas, el mapeo de cobertura natural y proyectos regionales relacionados carecen de eficacia. Durante la década pasada, NatureServe ha trabajado junto con el Gap Analysis Program y con otras agencias en los Estados Unidos para mapear la vegetación existente usando la Clasificación Nacional de Vegetación de los Estados Unidos (USNVC). El US-NVC es un sistema jerárquico de reglas para la descripción de vegetación actual. Esta experiencia ha demostrado la necesidad de desarrollar unidades de mapeo con escalas conceptuales intermedias entre los niveles mas preciso de "Alianza" (de composición) y mas general de "Formación" (de fisonomía) del US-NVC. La clasificación de unidades se llama "sistemas ecológicos terrestres" de NatureServe define mas de 630 unidades de "escala-intermedia" y se base en patrones naturales de la vegetación existente en los 48 estados contiguos de Los Estados Unidos. Los sistemas ecológicos se describen como múltiples comunidades de plantas que tienen tienden a ocurrir juntas en ambientes recurrentes y/o con similares dinámicas ecológicas. Debido a la integración de ambientes característicos con los patrones de vegetación dentro del concepto de cada unidad, este sistema de clasificación se presta para el modelaje utilizando variables bio-físicas, y para la caracterización de hábitats de la vida silvestre. Estas unidades son fácilmente aplicables al mapeo de cobertura natural y se pueden aumentar usando modificadores que reflejan variantes específicas de composición y estructura, lo que resulta en mapas robustos y estandardizados. El mapeo de cobertura natural fue realizado para todo el suroeste de los Estados Unidos por el Proyecto Southwest Regional Gap Analysis cartografiando 109 unidades de sistemas ecológicos, actualmente este mapa es el más detallado entre los mapas existentes de cobertura natural a escala regional. La clasificación de sistemas ecológicos terrestres provee una conexión directa y sistemática a la Clasificación Nacional de Vegetación de los Estados Unidos y también podría facilitar un contexto muy útil para la integración con otros conceptos de clasificación ecológica producidos por el gobierno federal de los Estados Unidos.

Key Words: ecological classification standard, ecological sites, Gap Analysis Program, land cover mapping, terrestrial ecological systems

This project was funded by USGS BRD, Gap Analysis Program. The Nature Conservancy provided support for development of the terrestrial ecological systems classification for the United States.

Correspondence: Patrick J. Comer, NatureServe, 4001 Discovery Drive, Suite 2110, Boulder, C0 80303. Email: pat_comer@natureserve.org

Manuscript received 5 April 2006; manuscript accepted 25 January 2007.

\section{INTRODUCTION}

Over the past decade, practitioners engaged in land cover mapping with the Gap Analysis Program (GAP) have gained much experience in mapping natural land cover at thematic and spatial resolutions relevant to natural resource management. 
Since the mid-1990s, the stated intention of GAP for land cover mapping has been to use a priori, nationally standardized vegetation classification in land cover mapping. The a priori approach establishes a target map legend at early stages to guide the mapping process. In contrast, a posteriori approaches to mapping land cover develop the map first, later applying appropriate labels to each map class. There has been much debate over the relative merits of a priori versus a posteriori approaches to land cover mapping. Kuchler (1988) argued that, given the difficulty of mapping vegetation, the a posteriori approach has many advantages. However, he conceded that the resulting maps are most applicable only in the mapped area or, at best, only short distances beyond the borders of the area. Because the geographic scope of GAP and other major land cover mapping efforts is regional, national, or international, basing mapping on a priori ecological classification is the most practical approach.

The US National Vegetation Classification System (US-NVC) (FGDC 1997; Grossman et al. 1998), which was developed by The Nature Conservancy in 1990s and is currently managed by NatureServe, provides 1 avenue for standardized a priori classification in support of land cover mapping throughout the United States. Because the developers of the US-NVC wanted to provide nationwide lists and descriptions of vegetation classification units within a decade, they chose to employ a combination of descriptive and quantitative methods to define the vegetation units. As quantitative data accumulate, each unit concept is improved as a result of quantitative analysis of floristic composition and abundance. Figure 1 depicts the current hierarchical structure of the US-NVC, with upper-level classification units defined solely by vegetation structure or physiognomy. These 5 upper levels range from Class to Formation and were formally adopted as the vegetation classification standard of the US Federal Geographic Data Committee (FGDC 1997). Floristic composition enters the US-NVC hierarchy at lower level units, called "alliance" and "association." Units for these levels are only available as a provisional set maintained by NatureServe, as FGDC works with the Ecological Society of America to develop standards for their description, analysis, peer review, and data management (Jennings et al. 2004). Associations are defined as a "plant community type of definite floristic composition, uniform habitat conditions, and uniform physiognomy." Associations are classified using diagnostic species from all structural layers (tree canopy, shrub layers, herbaceous layers). The alliance is a physiognomically uniform group of US-NVC associations sharing 1 or more dominant or diagnostic species, which as a rule are found in the uppermost strata of the vegetation (Mueller-Dombois and Ellenberg 1974). Since the mid-1990s, GAP has intended to map existing vegetation matching the scale and concept of the vegetation alliance. With support from GAP, alliances have been described nationally in the US-NVC (e.g., Sneddon et al. 1994; Drake and Faber-Langendoen 1997; Weakley et al. 1998; Reid et al. 1999).

However, GAP efforts to map vegetation at statewide scales have faced considerable difficulty achieving desired map accuracy using US-NVC alliances. Not all vegetative communities defined as individual alliances occur in sufficiently large (e.g., 0.5-5 ha) and distinctive patches to be readily mapped using satellite imagery and other ancillary data. As a result,

\section{FORMATION CLASS \\ FORMATION SUBCLASS FORMATION GROUP FORMATION SUBGROUP \\ Physiognomic levels FORMATION}

Floristic levels

ALLIANCE

ASSOCIATION

Figure 1. Current hierarchical structure of the US National Vegetation Classification (US-NVC) is composed of 5 upper-level classification units defined solely by vegetation structure or physiognomy and 2 lower levels defined by floristic compositions. The 5 upper levels were formally adopted as the vegetation classification standard of the US Federal Geographic Data Committee (FGDC 1997).

many state-level GAP land cover classes reflect varying combinations of alliances. These combinations vary in scale and composition within and across states, which in turn can preclude attempts to join maps from multiple states. For example, portions of the Colorado Plateau region were initially mapped by 4 state Gap Analysis projects in the 1980s and early 1990s (e.g., Edwards et al. 1995). These projects mapped pinyon and juniper woodlands in 7 different pinyon and juniper woodland land cover classes in Arizona compared to 2 classes in Colorado and Utah. In northwestern New Mexico, pinyon and juniper woodlands were mapped as part of the open or closed Rocky Mountain/Great Basin Evergreen Conifer Woodland land cover classes. For more examples of the regional vegetation classification and mapping issues related to state boundaries, see compiled state GAP maps available on the NBII Web site at http://gapmap.nbii.gov/generatethememap. php? category $=$ landcover\&statelist $=\mathrm{NM}$.

In 1998, GAP was encouraged to adopt a regional operating framework for future efforts (Eve and Merchant 1998). Southwest Regional Gap Analysis Project (SWReGAP) represented the first of these regional efforts, forming a multiinstitutional collaborative project of 5 state cooperators (Arizona, Colorado, Nevada, New Mexico, and Utah) and NatureServe. The purpose of this project was to map and assess biodiversity representation in conservation areas for a region comprising approximately 1.4 million $\mathrm{km}^{2} \quad(540,000$ square miles) in the interior southwestern United States This effort would provide an updated and standardized spatial data set for land cover, terrestrial vertebrate distributions, and land stewardship status.

While practitioners of the SWReGAP effort originally intended to map vegetation at the US-NVC alliance level (some 500 described units in the project area), the complexity of southwestern vegetation precluded attempts to map these types, and mapping the next broader level of the US-NVC hierarchythe formation-was deemed undesirable because those units do not reflect differences in floristic composition.

In response to this need for a nationally consistent, mesoscale, near-natural land cover legend for GAP and other broad-scale mapping efforts, NatureServe initiated development of the Terrestrial Ecological Systems Classification for the United States, which currently defines over 630 mesoscale standardized ecological units (Comer et al. 2003; http:// www.natureserve.org/explorer/). SWReGAP chose to use these 
midscale classification units to create a more accurate, nationally integrated map. This new approach to ecological system-based map units would: 1) allow more broadly defined map units to be utilized to achieve desired map accuracy, 2) maintain a direct link to the US-NVC, and 3) not preclude the ability of future analysts to meet the stated "alliance-level" goal in the future.

Lowry et al. (2005) provide detail on mapping methods and multistate collaboration for the SWReGAP effort. The goal of the SWReGAP land cover mapping effort was to produce a high-quality map of natural land cover and land use classes, with minimum map units of approximately one-half hectare in size, using a repeatable mapping methodology that could be consistently applied by several mapping teams. Methods involved both inductive and deductive modeling, combining spatial data on climate, landform, substrate, vegetation structure, and land use. Approximately 93000 georeferenced sample locations were used to "train" models for map production and for model validation, with the majority of the land cover classes discriminated using decision tree classifiers.

Here we provide additional background on the concepts and development of the terrestrial ecological systems classification, along with initial results and lessons learned from their application to land cover mapping in the southwestern United States. We also include discussion of the potential interrelationships of these concepts to other ecological classification concepts, such as ecological site descriptions being developed by the Natural Resource Conservation Service (NRCS). Integrated use of multiple classification concepts should facilitate a wide range of applications for conservation and resource management.

\section{TERRESTRIAL ECOLOGICAL SYSTEMS CLASSIFICATION}

\section{Definition and Concept}

A terrestrial ecological system is defined as a group of plant community types that tend to naturally co-occur with similar environmental settings, ecological dynamics, and/or environmental gradients. A given terrestrial ecological system will typically manifest itself in upland and/or wetland patches from tens to thousands of hectares in size and persist for 50 or more years. Environmental settings may include a variety of landform, soil surface, and bedrock features, such as relative slope position, soil depth, physical texture, and chemistry of parent materials. Ecological dynamics include natural disturbances such as fire and flooding. Local-scale environmental gradients include those defined by hydrologic and/or climatic fluctuations that result in repeating vegetation zonation. Updated descriptions of these classification units may be viewed at the NatureServe Web site at http://www.natureserve.org/ explorer/.

By plant community type, we refer to floristic classification units at the association level of the US-NVC (Grossman et al. 1998; Jennings et al. 2004; NatureServe 2006) or, if these are not available, other comparable vegetation units. US-NVC associations are used wherever possible to consistently describe the component plant communities of each terrestrial system type. While not all plant communities listed for a given ecological system would be expected to occur in every patch, the listed assemblage should be predictably encountered across multiple patches throughout the range of each system type.

Like the US-NVC, we employ a combination of descriptive and quantitative methods to define types. Initial phases have been descriptive, first establishing generalized spatial and temporal bounds for each unit, then using a series of diagnostic classifiers to further define each unit. Terrestrial ecological systems are defined within geographic and temporal ranges that are intermediate between those commonly considered for local stand and regional landscape-scale analyses, encompassing a range from tens to thousands of hectares and 50 to hundreds of years (Delcourt and Delcourt 1988). These mesoscale concepts are intended to constrain the definition of system types to scales that are of prime interest for conservation and resource management.

The temporal range we have chosen defines how we address successional change within each classification unit. Relatively short-term successional stages resulting from disturbances are encompassed within the concept of a given ecological system unit. For example, a given floodplain system may include both early successional herbaceous and shrub-dominated associations as well as mature woodland stages that form dynamic mosaics along tens of kilometers of a river. Similarly, many individual forest, shrubland, grassland, or sparsely vegetated systems will occur as multiple relatively stable states one could expect to encounter over a given 50-100-year period. Some of these states may form a continuous sequence of successional stages, while others may include more seemingly discontinuous-or even irreversible-states (e.g., a dune "blow-outs" or dune coppicing) (Briske et al. 2005, 2006).

\section{Diagnostic Classifiers}

As the definition for terrestrial ecological systems indicates, this is a multifactor approach to ecological classification, aiming to integrate vegetation with environmental setting and natural dynamics. Multiple environmental factors-or diagnostic classifiers-are evaluated and combined in different ways to explain the spatial co-occurrence of US-NVC associations (Table 1). Diagnostic classifiers include several factors representing bioclimate, biogeographic history, physiography, landform, physical and chemical substrates, dynamic processes, landscape juxtaposition, and characteristic native vegetation structure and composition. Diagnostic classifiers are used here in the sense of Di Gregorio and Jansen (2000) to provide a framework for defining ecological systems in a "modular" fashion that aggregates classifiers in multiple, varying combinations without imposing a specific nested hierarchy. This is in contrast to, for example, the organizational and conceptual hierarchy of the US-NVC. The nested US-NVC hierarchy groups associations into alliances based on common dominant or diagnostic species. This provides more of a taxonomic aggregation with no presumption that associations co-occur in a given landscape. The ecological system unit links US-NVC associations using multiple factors that explain why they tend to be found together in a given landscape. For example, associations of gypsophilous plants such as Sporobolus nealleyi-Calylophus hartwegii Herbaceous Vegetation and Tiquilia hispidissima/Sporobolus nealleyi Dwarf-shrubland are 
Table 1. Categories and examples of diagnostic classifiers used to define terrestrial ecological systems in a multifactor approach that integrates vegetation with environmental setting and natural dynamics.

\begin{tabular}{l}
\hline Ecological divisions \\
Continental bioclimate and phytogeography \\
Bioclimatic variables \\
Regional bioclimate \\
Environment \\
Landscape position, hydrogeomorphology \\
Soil characteristics, specialized substrate \\
Ecological dynamics \\
Hydrologic regime \\
Fire regime \\
Landscape juxtaposition \\
Upland-wetland mosaics \\
Vegetation \\
Vertical structure and patch type \\
Composition of component associations \\
Abundance of component associations \\
\hline
\end{tabular}

characteristic of Chihuahuan Gypsophilous Grassland and Steppe ecological system. These 2 floristically similar associations are organized into 2 distinct formations and alliances (herbaceous vegetation vs. dwarf shrubland) of the US-NVC but are units in the same terrestrial ecological system. Therefore, ecological systems tend to be better "grounded" as ecological units than most US-NVC alliances and are more readily identified, mapped, and understood as practical ecological classification units.

Ecological divisions are used as a starting point for integrating broad-scale factors that explain some but not all of the distribution of an ecological system type. Ecological divisions are subcontinental landscapes reflecting both climate and biogeographic history, adapted from Bailey (1996, 1997) at the division scale (Fig. 2). Continent-scaled climatic variation, reflecting variable humidity and seasonality (e.g., Mediterranean vs. dry continental vs. humid oceanic), are captured in these units, as are broad patterns in phytogeography (e.g., Takhtajan 1986). The division lines were further modified from ecoregions established by The Nature Conservancy (Groves et al. 2002) and the World Wildlife Fund (Olson et al. 2001) throughout the Western Hemisphere. These divisions aid the development of ecological system concepts because they describe regional patterns of climate, physiography, disturbance regimes, and biogeographic history. Division boundaries are not applied here as a spatially nested hierarchy commonly used in ecological land classifications across North America (e.g., ECOMAP 1993; McNab and Avers 1994; Cleland et al. 2005; West et al. 2005; USDA, NRCS 2006). In those instances, broader landscape units constrain the spatial distribution of each finer-scale classification unit. Here, we use them to help encapsulate the broad-scale factors influencing the system, without rigidly forcing them to be spatially constrained within a nested hierarchy.

Subregional bioclimatic factors are also useful for classification purposes, especially where relatively abrupt gradients exist. We integrated several global bioclimatic categories of
Rivas-Martinez (1997) to define a set of subregional climatic classifiers. These include relative temperature, moisture, and seasonality. They aid in describing life zone concepts (e.g., “maritime," “lowland," “montane," “subalpine," “alpine”) from arctic through tropical latitudes.

Within the context of biogeographic and bioclimatic factors, ecological composition, structure, and function are strongly influenced by factors determined by local physiography, landform, and surface substrate in both upland and wetland environments. Some environmental variables are described through existing, standard classifications and serve as excellent diagnostic classifiers for ecological systems. For example, soil moisture characteristics have been well described by the NRCS. Practical hydrogeomorphic classes are established for describing all wetland circumstances (Brinson 1993). Other factors, such as landforms and specialized soil chemistry, have in some instances been defined in standard ways to allow for their consistent application as diagnostic classifiers.

Many dynamic processes are sufficiently understood to serve as diagnostic classifiers in ecosystem classification. In many instances, a characteristic disturbance regime may provide the single driving factor that distinguishes system types. For example, composition and structure of many similar woodland and forest systems are distinguishable based on the frequency, intensity, periodicity, and patch characteristics of wildfire (Barnes et al. 1998). Many wetland systems are distinguishable based on the hydroperiod as well as water flow rate and direction (Cowardin et al. 1979; Brinson 1993). When characterized in standard form (e.g., Frost 1998), these and other dynamic processes can be used in a multifactor classification.

Local-scale climatic regime, physiography, substrate, and dynamic processes can often result in recurring mosaics. For example, large rivers often support recurring patterns of levee, floodplain, and back swamps, all resulting from seasonal hydrodynamics that continually scour and deposit sediment. Many depressional wetlands or lakeshore dune and swale complexes have predictable vegetation zonation driven by recurrent landforms and water level fluctuation. The recurrent juxtaposition of recognizable plant communities provides a useful and important criterion for multifactor classification.

As is well recognized in traditional approaches to vegetation classification, both the physiognomy and the composition of vegetation suggest much about ecosystem composition, structure, and function. However, the relative significance of vegetation physiognomy may vary among different ecosystems, especially at local scales. For example, many upland systems support vegetation of distinct physiognomy in response to fire frequency and soil moisture regimes. In general, physiognomic distinctions such as "forest and woodland," "shrubland" "savanna," "shrub steppe," "grassland," and "sparsely vegetated" are useful distinctions in upland environments. On the other hand, needleleaf or broadleaf tree species that are either evergreen or deciduous may co-occur in various combinations due more to variable responses to natural disturbance regimes or human activities than to current environmental conditions. Many wetland systems could support herbaceous vegetation, shrubland, and forest structures in the same location, again based on the particular strategies of the species involved and local site history. Therefore, while recognizable differences in 


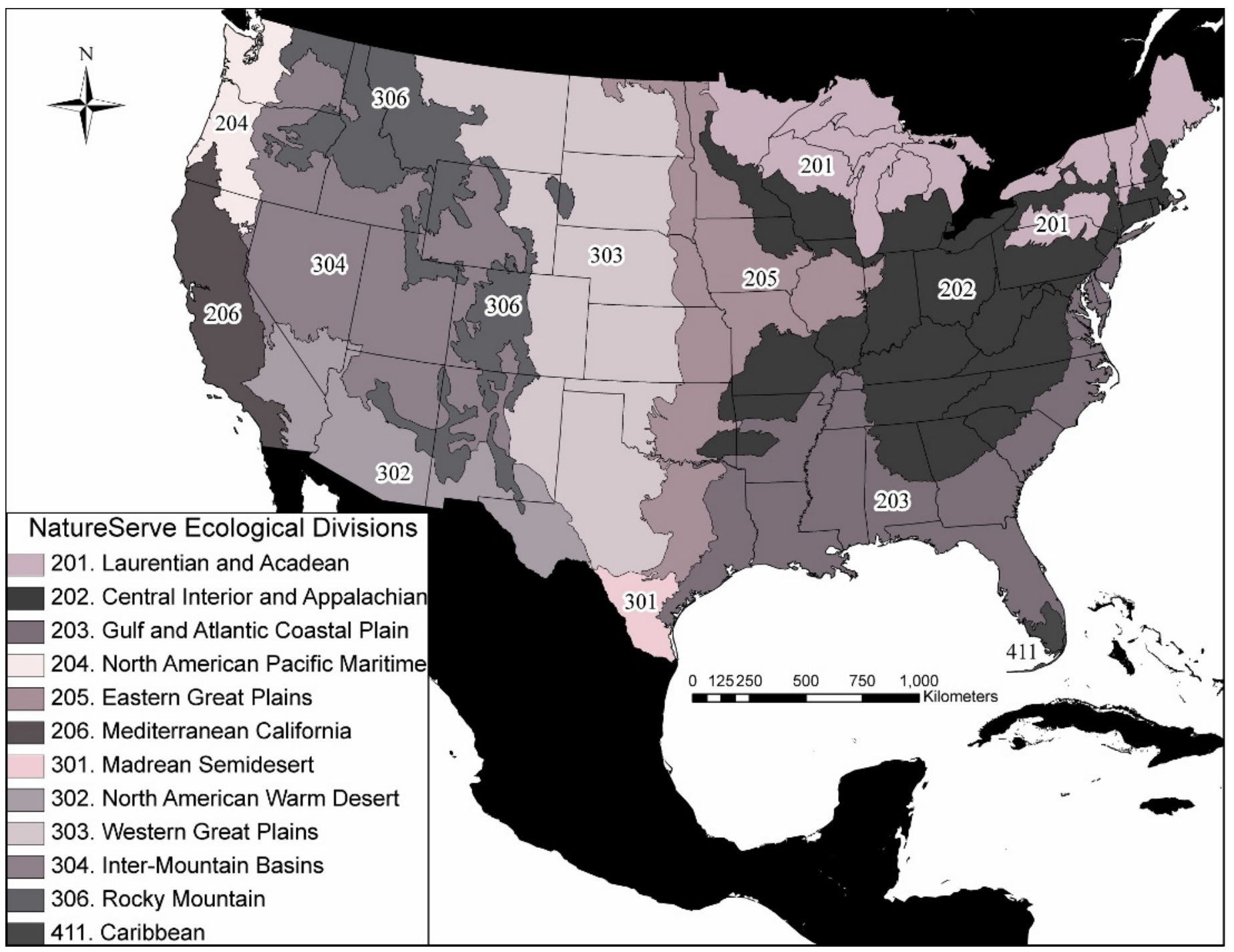

Figure 2. Ecological divisions (12) in the coterminous United States modified from division-scale ecoregions of Bailey (1996, 1997). Ecological divisions are subcontinental landscapes used to integrate both climate and broad-scale biogeographic factors that affect the distribution of ecological system types. The SWReGAP project area includes parts of 4 divisions: Inter-Mountain Basins, North American Warm Desert, Rocky Mountain, and Western Great Plains.

vegetation physiognomy may initially suggest distinctions among ecosystem types, knowledge of vegetation composition should be relied on more heavily to indicate significant distinctions.

\section{Procedures to Classify Terrestrial Ecological Systems}

As in traditional forms of vegetation classification, we recognize beta diversity, or the turnover of native species composition and abundance through space, as a primary means of differentiating natural ecosystem types. The task of classification is to recognize where that turnover is relatively abrupt and to explain why that abrupt change occurs on the ground. However, as previously stated, we currently lack comprehensive sample data to support a solely quantitative approach to classification on a national scale. Thus, initial phases to define terrestrial ecological systems types have been descriptive. Conceptual decision trees can serve an important function in this regard by describing the integration of multiple factors at varying scales of precision-starting with very broad descriptive categories, then integrating more precise characteristics at lower levels (Table 2). The categories within this decision matrix integrate major differences in environment settings and dynamics that result in differential biotic assemblages.

Standardized vegetation classification units, especially at the local scale described by the US-NVC association concept, provide another useful tool for qualitative description of ecological system units. In locations where US-NVC associations are well developed, they serve as a useful summary of detailed quantitative data on the physiognomy and floristics of component vegetation. Initial listings of US-NVC associations can be used to evaluate the relative vegetation similarity among ecological system units. For example, 2 apparently similar shrubland-dominated ecosystems could be characterized in terms of their characteristic associations. Component associations may also be used to describe many component "states" in 
Table 2. A sample decision matrix used to classify selected shrubland and shrub steppe terrestrial ecological systems that occur in the Great Basin portion of the Inter-Mountain Basins Division. It demonstrates the integration of multiple ecological and environmental factors at varying scales from very broad descriptive categories such as life zone and landscape position, then to more discriminating characteristics such as landform/topography, substrates, and ecological dynamics. The number of NVC associations included in each system illustrates variability within each ecological system.

GREAT BASIN UPLAND SHRUBLANDS AND SHRUB STEPPES

\begin{tabular}{|c|c|c|c|c|c|c|}
\hline \multicolumn{5}{|c|}{ Ecological and Environmental Diagnostic Classifiers } & \multirow[b]{2}{*}{ Ecological Systems } & \multirow{2}{*}{$\begin{array}{l}\text { Number } \\
\text { of NVC } \\
\text { Assoc }\end{array}$} \\
\hline $\begin{array}{l}\text { Life } \\
\text { Zone }\end{array}$ & $\begin{array}{l}\text { Landscape } \\
\text { Position }\end{array}$ & $\begin{array}{l}\text { Landform/ } \\
\text { Topography }\end{array}$ & Substrates & Ecological Dynamics & & \\
\hline \multirow{3}{*}{$\begin{array}{l}\text { 氖 } \\
\text { 总 }\end{array}$} & \multirow{3}{*}{$\begin{array}{l}\text { Lower } \\
\text { Montane }\end{array}$} & $\begin{array}{l}\text { Ridge, Summit, } \\
\text { Upper Slopes, } \\
\text { Sideslope }\end{array}$ & Rocky soils & \multirow{2}{*}{$\begin{array}{l}\text { Long Disturb Interval } \\
\text { (>25yrs) Fire Regime: } \\
\text { Patch/Medium Intensity }\end{array}$} & $\begin{array}{l}\text { Inter-Mountain Basins } \\
\text { Mountain Mahogany } \\
\text { Woodland and Shrubland }\end{array}$ & 14 \\
\hline & & $\begin{array}{l}\text { Plateau, } \\
\text { Mountain side; } \\
\text { Mountain valley }\end{array}$ & $\begin{array}{l}\text { Deeper } \\
\text { soils }\end{array}$ & & $\begin{array}{l}\text { Inter-Mountain Basins } \\
\text { Montane Sagebrush } \\
\text { Steppe }\end{array}$ & 47 \\
\hline & & $\begin{array}{l}\text { Mountain side, } \\
\text { Canyons, Foot } \\
\text { Slopes }\end{array}$ & \multirow{2}{*}{$\begin{array}{l}\text { Shallow, } \\
\text { rocky, } \\
\text { coarse } \\
\text { textured, } \\
\text { non-saline } \\
\text { soils }\end{array}$} & $\begin{array}{l}\text { Intermed Disturb Interval } \\
\text { (13-25yrs) Fire Regime: } \\
\text { Patch/ High Intensity }\end{array}$ & $\begin{array}{l}\text { Great Basin SemiDesert } \\
\text { Chaparral }\end{array}$ & 13 \\
\hline \multirow{5}{*}{ 氶 } & \multirow{2}{*}{ Foothill } & $\begin{array}{l}\text { Ridge, Summit, } \\
\text { Upper Slopes }\end{array}$ & & $\begin{array}{l}\text { Long Disturb Interval } \\
\text { ( }>25 \mathrm{yrs})\end{array}$ & $\begin{array}{l}\text { Great Basin Xeric Mixed } \\
\text { Sagebrush Shrubland }\end{array}$ & 33 \\
\hline & & \multirow{3}{*}{$\begin{array}{l}\text { Lower Slopes, } \\
\text { Plains, Plateaus, } \\
\text { Valley Bottom } \\
\text { and Flats }\end{array}$} & $\begin{array}{l}\text { Variable } \\
\text { textured } \\
\text { soils }\end{array}$ & $\begin{array}{l}\text { Very Short Disturb } \\
\text { Interval (1-6yrs) }\end{array}$ & $\begin{array}{l}\text { Inter-Mountain Basins } \\
\text { Semi-Desert Shrub- } \\
\text { Steppe }\end{array}$ & 34 \\
\hline & \multirow{3}{*}{$\begin{array}{l}\text { Basin and } \\
\text { Valley } \\
\text { Bottoms }\end{array}$} & & \multirow{2}{*}{$\begin{array}{l}\text { Deep, well } \\
\text { drained, } \\
\text { non-saline } \\
\text { soils }\end{array}$} & $\begin{array}{l}\text { Long Disturb Interval } \\
\text { (>25yrs) Fire Regime: } \\
\text { Landscape/ High Intensity }\end{array}$ & $\begin{array}{l}\text { Inter-Mountain Basins } \\
\text { Big Sagebrush Shrubland }\end{array}$ & 55 \\
\hline & & & & $\begin{array}{l}\text { Intermed Disturb Interval } \\
\text { (13-25yrs) Fire Regime: } \\
\text { Patch/ High Intensity }\end{array}$ & $\begin{array}{l}\text { Inter-Mountain Basins } \\
\text { Big Sagebrush Steppe }\end{array}$ & 27 \\
\hline & & $\begin{array}{l}\text { Alluvial Flat, } \\
\text { Saline Basin }\end{array}$ & Saline soils & $\begin{array}{l}\text { Long Disturb Interval } \\
(>25 \mathrm{yrs})\end{array}$ & $\begin{array}{l}\text { Inter-Mountain Basins } \\
\text { Mixed Salt Desert Scrub }\end{array}$ & 57 \\
\hline
\end{tabular}

conceptual state-and-transition models. These models help to clarify assumptions about expected vegetation dynamics within patches of a given ecological system type, just as has been done for selected ecological site concepts in eastern Montana (Kudray and Cooper 2005).

While beta diversity is a primary consideration in distinguishing among classification units, the relative abundance of specific community types can also be an important consideration. For example, riparian and floodplain systems may share many plant associations because of their adaptation for dispersal along a seasonally flowing river. However, there may be substantial differences in the relative abundance of vegetation between, for example, riparian systems with small, flash-flood stream dynamics and a large, well-developed river floodplain many kilometers downstream. Measurement of both vegetation patterns and environmental factors that support them are needed to adequately address this facet of classifying ecological systems.

Finally, we have developed a standard nomenclature for terrestrial ecological systems. Biogeography and bioclimate are often used, along with reference to vegetation structure, composition, and/or local environment, to name each unit.
For example, an "Inter-Mountain Basins" ecological system type is predominantly ( $>80 \%$ of its total range) found within the Inter-Mountain Basins Division. A "Great Basin" type falls primarily within that Province-scale ecoregion of Bailey (1997), nested within the larger Inter-Mountain Basins Division. The Great Basin Xeric Mixed Sagebrush Shrubland occurs with several sagebrush codominants within a specific low-elevation environmental envelope in and around the Great Basin.

\section{SWReGAP Map Legend Development}

There are approximately 636 terrestrial ecological system types currently described for the lower 48 United States, of which 143 , or $24 \%$, are known to occur within the 5 -state SWReGAP project area. This formed the starting point for creating the map legend to natural land cover. The legend of natural land cover types and land use classes were organized hierarchically within 13 broader land cover classes used in the National Land Cover Data set (NLCD) (Homer et al. 2004). Because some ecological system types naturally occur as relatively small patches $(<1 \mathrm{ha})$ or occur only along a narrow periphery of this large mapped area, they were removed from the draft legend, as they occurred below the minimum mapping unit or otherwise 
Table 3. The SWReGAP land cover mapping legend's 125 map classes are summarized into National Land Cover Data (NLCD) classes. This provides a general overview by percent area mapped regionally and by state to illustrate variability in vegetation structure and land use. NLCD classes are organized first by natural land cover and land use class and second from most to least abundant regionally.

\begin{tabular}{|c|c|c|c|c|c|c|}
\hline \multirow[b]{2}{*}{ NLCD class } & \multicolumn{5}{|c|}{ Percent area by state } & \multirow[b]{2}{*}{ Percent region } \\
\hline & $A Z$ & $\mathrm{CO}$ & NV & NM & UT & \\
\hline Shrub/scrub & 50.6 & 14.8 & 63.7 & 19.6 & 33.1 & 36.5 \\
\hline Grassland/herbaceous & 14.6 & 28.4 & 9.9 & 47.4 & 12 & 23.3 \\
\hline Evergreen forest & 25.1 & 23.4 & 13.3 & 24.9 & 20.4 & 21.6 \\
\hline Sparsely vegetated/barren & 4.1 & 2.1 & 4.2 & 2.8 & 14.8 & 5.1 \\
\hline Woody wetland & 0.9 & 2.8 & 4.2 & 1.4 & 4 & 2.6 \\
\hline Deciduous forest & 0.1 & 4.2 & 0.5 & 0.5 & 3.3 & 1.6 \\
\hline Mixed forest & 0 & 0.7 & $<0.1$ & 0.1 & 0.6 & 0.2 \\
\hline Emergent herbaceous wetland & $<0.1$ & 0.5 & 0.1 & 0.1 & 0.4 & 0.2 \\
\hline Agriculture & 1.9 & 19.6 & 0.8 & 1.9 & 4.2 & 5.5 \\
\hline Altered or disturbed & 0.5 & 1.8 & 2.4 & 0.3 & 2.8 & 1.5 \\
\hline Open water & 0.2 & 0.5 & 0.5 & 0.3 & 3.1 & 0.8 \\
\hline Developed, medium-high intensity & 1.4 & 0.4 & 0.1 & 0.4 & 0.5 & 0.5 \\
\hline Developed, open space-low intensity & 0.6 & 0.7 & 0.3 & 0.3 & 0.9 & 0.5 \\
\hline
\end{tabular}

could not be mapped accurately in this regional scale land cover. These classification units could be subsequently mapped in local mapping efforts. Additional land cover classes were established to characterize altered/disturbed vegetation, other land cover, and land uses. Existing knowledge among project cooperators was sufficient to establish the draft legend for the project, organized into a series of mapping zones (Lowry et al. 2005). Dichotomous field keys were also developed for all ecological system types to assist with field data collection and communicating distinctions among classification units. The draft legend guided field sampling effort and selection of spatial data for subsequent spatial modeling.

\section{RESULTS AND DISCUSSION}

Mapping forms a critical phase in the development of any ecological classification. Classification concepts remain simply concepts until field data are gathered and assumptions are fieldtested. Producing high-quality maps of classification units is one major form of field testing by classifying sites on the ground and by accurately distinguishing different land cover types. Through the SWReGAP effort, ecological system classification concepts were tested and refined. Of the 143 types that could occur within the region, 109 are found in enough large patches and had adequate numbers of georeferenced samples to map using inductive modeling. The SWReGAP Land Cover Map is available at http://earth.gis.usu.edu/ swgap/landcover.html. The map retains a $30-\mathrm{m}$ pixel resolution for predictor layers and a minimum map unit of 0.40 ha (1 acre) for all map classes. Map validation procedures indicated an overall map accuracy of $61 \%$ (kappa statistic $0.60 ; n=$ 17030 ) for 85 natural and land use classes with sufficient numbers $(>20)$ of reference samples. The predominant ecological system types typically had better validation results than small or linear patch types or for types found along the periphery of the project area that had relatively few training sites and reference samples. This was not a true accuracy assessment but rather an internal validation of the mapping models. It was done for the more abundant types by using $20 \%$ of the training sites, which were withheld from the original model. After validation, these training sites were added back into the final mode to improve final mapping accuracy. See Lowry et al. (2005) for additional details on land cover mapping validation methods and results.

For SWReGAP land cover mapping, a total of 125 map classes are represented, including 109 natural land cover types, 11 altered/disturbed vegetation types, 3 land use types, open water, and a nonspecific barren land type. Table 3 includes an overview of area by major NLCD class summarizing common trends. Approximately $92 \%$ of the region's landscape included natural land cover, with approximately $7 \%$ of the total area in apparently altered vegetation or agricultural land uses. Approximately $1 \%$ of the region was in some form of more intensive land use. Terrestrial ecological systems, organized under the NLCD classes of shrub/scrub (36.5\%), grasslands/ herbaceous $(23.3 \%)$, and evergreen forests $(21.6 \%)$, when combined, extend over $80 \%$ of the region. These are followed by sparsely vegetated/barren types $(5.1 \%)$, woody wetlands $(2.6 \%)$, deciduous forests $(0.2 \%)$, and herbaceous wetland $(0.2 \%)$, respectively. In proportion to their state's total area, Arizona and Nevada have a relatively high extent of montane shrubland and desert scrub, whereas Colorado and New Mexico have a relatively high extent of grasslands. Proportional extent of evergreen forest was more evenly distributed among these states. Sparsely vegetated land cover is proportionally highest in Utah. Agriculture land (cultivated and/or irrigated), which is regionally the fifth most abundant of all land cover types $\left(5.5 \%\right.$, or $\left.75981 \mathrm{~km}^{2}\right)$, makes up $20 \%$ of Colorado but only $4 \%$ of Utah and less than $2 \%$ of each of the remaining states. Regionwide, altered and disturbed classes totaled $20315 \mathrm{~km}^{2}(1.5 \%)$, developed land totaled $14964 \mathrm{~km}^{2}(1.1 \%)$, and open water totaled $11023 \mathrm{~km}^{2}$ $(0.8 \%)$.

Relatively few terrestrial ecological system types account for the majority of natural land cover in these 5 states (Table 4). The 5 most abundant natural land cover types totaled $457551 \mathrm{~km}^{2}$ and made up $33 \%$ of the region. These include 
Table 4. Few of the 109 terrestrial ecological systems in the SWReGAP mapping legend account for the majority of natural land cover mapped in the project area with the 5 and 10 most abundant ecological systems comprising one-third and one-half of the area, respectively. The 15 most abundant types are listed with total area $\left(\mathrm{km}^{2}\right)$ and percent of the total area mapped.

\begin{tabular}{lcc}
\hline Regionally dominant ecological systems & Total area $\left(\mathrm{km}^{2}\right)$ & Percent of total area \\
\hline Western Great Plains Shortgrass Prairie & 113162 & $8.16 \%$ \\
Inter-Mountain Basins Big Sagebrush Shrubland & 108480 & $7.83 \%$ \\
Colorado Plateau Pinyon-Juniper Woodland & 97855 & $7.06 \%$ \\
Inter-Mountain Basins Mixed Salt Desert Scrub & 79294 & $5.72 \%$ \\
Sonora-Mojave Creosotebush-White Bursage Desert Scrub & 58760 & $4.24 \%$ \\
Great Basin Pinyon-Juniper Woodland & 50776 & $3.66 \%$ \\
Southern Rocky Mountain Ponderosa Pine Woodland & 50221 & $3.62 \%$ \\
Inter-Mountain Basins Semidesert Shrub-Steppe & 47618 & $3.44 \%$ \\
Apacherian-Chihuahuan Semidesert Grassland and Steppe & 45711 & $3.30 \%$ \\
Inter-Mountain Basins Montane Sagebrush Steppe & 40654 & $2.93 \%$ \\
Sonoran Paloverde-Mixed Cacti Desert Scrub & 39791 & $2.87 \%$ \\
Great Basin Xeric Mixed Sagebrush Shrubland & 35434 & $2.56 \%$ \\
Inter-Mountain Basins Semidesert Grassland & 33640 & $2.43 \%$ \\
Apacherian-Chihuahuan Mesquite Upland Scrub & 31683 & $2.29 \%$ \\
Chihuahuan Mixed Desert and Thorn Scrub & 27407 & $1.98 \%$ \\
Total & 860486 & $62.08 \%$ \\
\hline
\end{tabular}

Western Great Plains Shortgrass Prairie, Inter-Mountain Basins Big Sagebrush Shrubland, Colorado Plateau Pinyon-Juniper Woodland, Inter-Mountain Basins Mixed Salt Desert Scrub, and Sonora-Mojave Creosote-White Bursage Desert Scrub. The 10 most abundant types encompassed $692531 \mathrm{~km}^{2}$, or half $(50 \%)$ of the region, and the 15 most abundant types covered $860486 \mathrm{~km}^{2}$, almost two-thirds $(62 \%)$ of the region. The remaining 94 ecological systems each comprise less than $2 \%$ of the region. Distribution of these most abundant ecological system types across the region is quite variable. The most abundant type, Western Great Plains Shortgrass Prairie, is restricted to the eastern plains of Colorado and New Mexico and makes up $17 \%$ and $21 \%$ of each state, respectively. In contrast, the second most abundant type, Inter-Mountain Basins Big Sagebrush Shrubland, occurs in all 5 states and varies from $1.2 \%$ of New Mexico to $23 \%$ of Nevada. Lowry et al. (2005) provides a complete summary of land cover classes mapped for the SWReGAP effort.

Terrestrial ecological systems tend to form map units that are more thematically detailed than have been typically produced for state-level land cover mapping (e.g., Edwards et al. 1995). One example to help clarify the ecological range of these units is found in a group of related sagebrush (Artemisia spp. L.)dominated ecological system types. Six of the 9 sagebrushdominated systems documented for the western United States were mapped by SWReGAP effort. Four of the 6 sagebrushdominated systems have variable but generally dense shrub canopies with relatively low perennial grass cover (Colorado Plateau Mixed Low Sagebrush Shrubland, Great Basin Xeric Mixed Sagebrush Shrubland, Inter-Mountain Basins Big Sagebrush Shrubland, Wyoming Basins Low Sagebrush Shrubland). Two are shrub steppes (Inter-Mountain Basins Big Sagebrush Steppe, Inter-Mountain Basins Montane Sagebrush Steppe) with a relatively dense perennial grass layer and more open shrub canopies. Big sagebrush (Artemisia tridentata Nutt.) dominates the shrub layers of Inter-Mountain Basins Big Sagebrush Shrubland, Inter-Mountain Basins Big Sagebrush
Steppe, and Inter-Mountain Basins Montane Sagebrush Steppe, although different combinations of big sagebrush subspecies, environment, and cover of perennial herbaceous layer distinguish these 3 types. Low sagebrush types are dominated by black sagebrush (Artemisia nova A. Nels.) or other more geographically restricted low sagebrush taxa, such as $A$. arbuscula Nutt. ssp. arbuscula, A. arbuscula Nutt. ssp. longicaulis Winward \& McArthur, A. arbuscula Nutt. ssp. longiloba (Osterhout) L. Shultz, A. bigelovii Gray, and A. tripartita Rydb. ssp. rupicola Beetle. Artemisia tridentata Nutt. ssp. wyomingensis Beetle \& Young may be present or even codominant in some locations. The sagebrush steppe systems are most typical of either lower-elevation plains across the Columbia Plateau and Wyoming Basins, north of the project area, or throughout montane landscapes in the Intermountain West. The distribution of 2 of the ecological systems, InterMountain Basins Big Sagebrush Shrubland and Inter-Mountain Basins Montane Sagebrush, can be displayed well at a regional scale (Fig. 3).

\section{Mapping Challenges With Terrestrial Ecological Systems}

A common challenge presented in mapping established ecological classification concepts is coping with continuous variation in both vegetation composition and structure as well as a host of characteristic environmental attributes. Compositional turnover in space within a given ecological system varies from type to type, and different types share common attributes in varying degrees. For example, multiple structural stages may characterize a given ecological system and lead to ambiguities in determining appropriate labeling of sample plots when no contextual information is included. Some of these challenges are overcome through mechanical steps of the mapping process (see Lowry et al. 2005). However, one avenue to cope with this variation, explored to only a limited degree in the SWReGAP effort, is to construct map legends with multiple, standardized levels of thematic resolution and then allow for standardized map class modifiers to describe variation in vegetation 


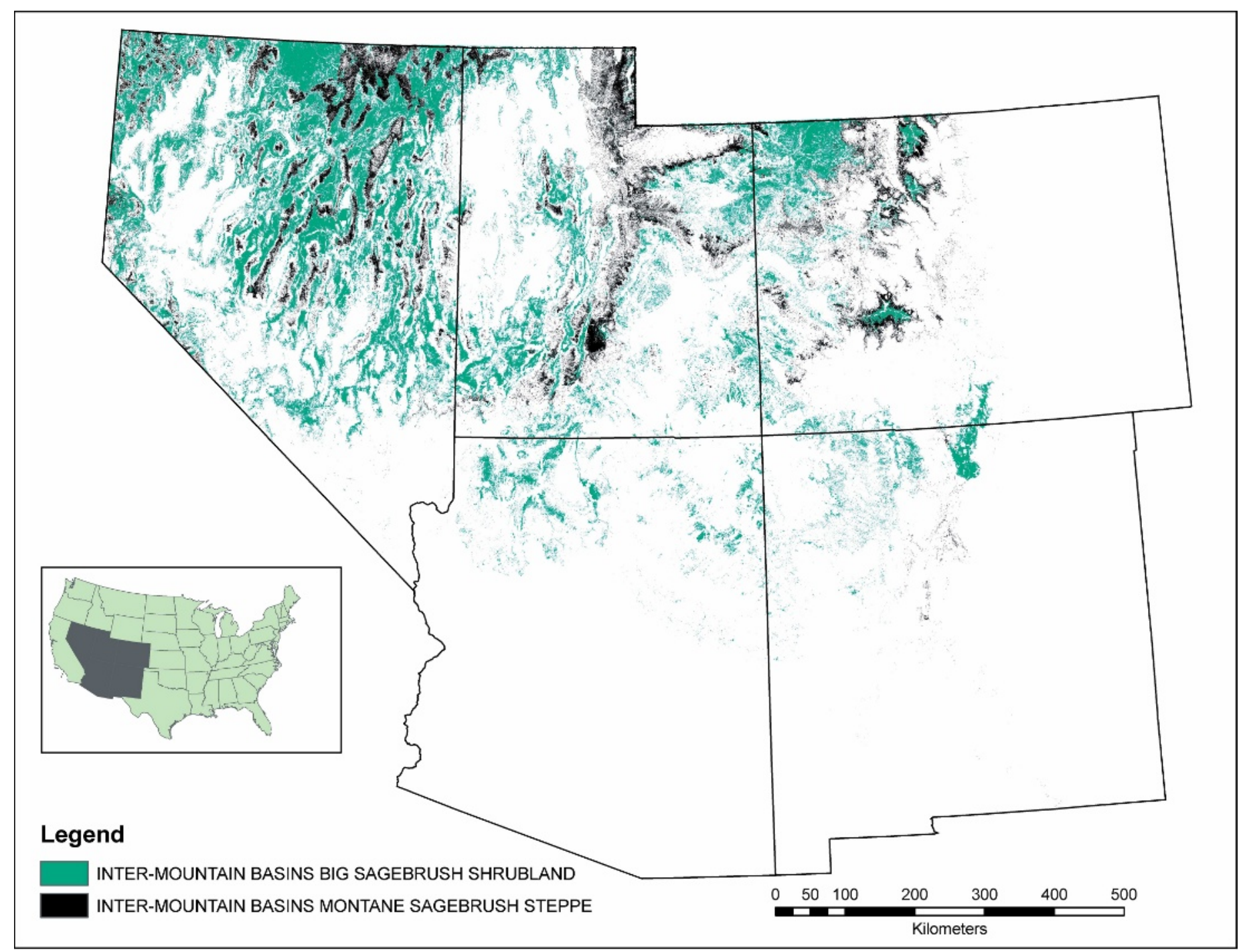

Figure 3. This map illustrates regional distributions of Inter-Mountain Basins Big Sagebrush Shrubland and Inter-Mountain Basins Montane Sagebrush Steppe within the SWReGAP project area. The regional context enables regional scale questions to be answered for these 2 widespread sagebrush ecological systems. These 2 ecological systems may co-occur in the same landscape but have different diagnostic classifiers, such as life zone and landscape position (see Tables 1 and 2).

structure. The regional map legend may be constructed to map ecological system concepts (and land use) comprehensively but allow for an additional layer, based on US-NVC alliance concepts, to be added where those units are feasibly mapped. This results in an additional, noncomprehensive map layer that can provide an added level of compositional detail where desired. Standard structural modifiers, defined using the NLCD classes (e.g., "scrub/shrub" patches within "evergreen forest") or finer-resolution classes based on height and density of woody vegetation, add much about the true nature of terrestrial ecosystems that is relevant to resource managers. Of course, any of these additions add to the demands for field data to support map production and accuracy assessment. However, developing multiscale (hierarchical) legends for mapping projects (be they regional or local in extent) would enable more detailed map units to be readily combined into the broader ecological system scale units and better integrate local mapping efforts with regional/national maps.
Even greater mapping challenges are posed by the dynamic nature of vegetation response to disturbance-be it natural or human induced — and our ability to recognize relevant temporal patterns while mapping. As mentioned previously, we use a time frame of 50-100 years to assist in conceptualizing ecological system types, subsuming most natural and characteristic successional stages into a given classification units concept. However, there are certainly circumstances where infrequently intense and/or widespread disturbance can alter vegetative composition and structure to a degree that it becomes difficult to distinguish between similar system types. For example, intense fires may remove shrub or tree components from sagebrush- or juniper-dominated steppe or savanna, leaving for many decades what appears to be a compositionally similar grassland system type. These ambiguities are only exaggerated when factoring in land use history. Although some past land uses can be readily distinguished and mapmakers can establish practical land cover classes to represent them, many past 
modifications to vegetation-be it through past livestock grazing, fire suppression, or nonnative species introductionscan be much more difficult to discern with data commonly in hand during map projects. These ambiguities will continue to be sources of error in map products such as that of SWReGAP.

\section{Integration With Other Classification Approaches}

A very important consideration in choosing ecological classification and mapping units is the potential for their integration with data derived from other classification approaches. As previously mentioned, ecological system concepts are developed using US-NVC associations. One intention of the USNVC is to provide a "crosswalking" standard for geographic data developed by US federal agencies (FGDC 1997). That is, while agencies are not required to directly classify and map USNVC concepts, they are encouraged to relate their data to USNVC concepts. Terrestrial ecological systems formalize that "crosswalking" process, providing a structure to report map products in terms of the FGDC standard (the component USNVC types found with each map class) while producing nationally standardized map classes.

Terrestrial ecological systems concepts may also offer an opportunity for better integration among the US-NVC and ecological site concepts being developed by the Bureau of Land Management and the NRCS as well as related ecological land classifications in development by the US Forest Service. Land classifications have provided a significant avenue to organize knowledge of ecological site potential and to describe complex vegetation patterns one observes in the field. Land-based units are often arranged within spatial hierarchies, and local land units are defined using characteristic landforms and soil series. If conceptualized and mapped effectively, these discrete land units provide a relatively stable, spatially explicit framework to develop conceptual state-and-transition models that describe likely dynamics occurring among distinct vegetative "states." Bestelmeyer et al. (2004, 2006) provide examples of how conceptual state-and-transition models can be used in range management and suggest how the process of creating these models could be improved. For example, a set of vegetative "states" (distinct vegetation structure/compositional assemblages) that in combination form relatively predictable patterns over time intervals relevant to management may be depicted as 1 large "box," and 1 or more "boxes" are then nested within the large box to depict component vegetative or structural "states" and the successional relationships between each (Bestelmeyer et al. 2004, 2006; Herrick et al. 2006). Many conceptual state-and-transition models have been developed using local knowledge, but more work is needed to better formalize how knowledge is documented and how these models relate to mapped features.

As currently defined and in relatively undisturbed locations, terrestrial ecological system concepts should match the intended definition for larger "box" concepts described by Bestelmeyer et al. (2004) and Herrick et al. (2006) -those broader, sometimes heterogeneous combinations of "states" that are predictably encountered over time intervals relevant to management. Also, the expected ecological distinctions between 2 terrestrial ecological system units should be at least as great as the expected distinctions between 2 ecological site
TERRESTRIAL ECOLOGICAL SYSTEM

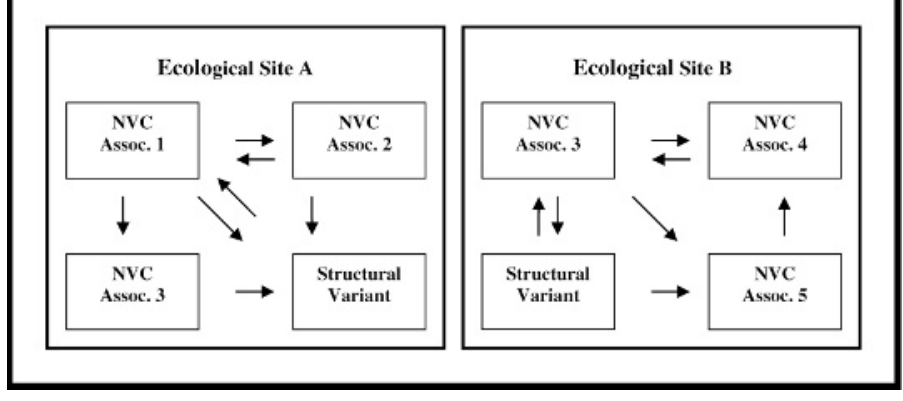

Figure 4. Conceptual relationships are illustrated between NatureServe Terrestrial Ecological Systems, NRCS Ecological Sites, and US-National Vegetation Classification associations with arrows indicating possible successional pathways. As currently defined ecological system concepts should include 1 or more ecological site concepts (A, B). The expected ecological distinctions between 2 terrestrial ecological systems should be at least as great as the expected distinctions between 2 ecological site concepts. Floristic composition varies within each ecological site with management actions and can be represented by US-NVC associations. The floristic variation between ecological sites tends to be narrower than between the conceptually broader ecological systems.

concepts. This means that, when manifested on the ground, ecological site concepts should closely match, or nest spatially, within the mapped example of a given terrestrial ecological system. There may be a 1-to-1 relationship in some cases, but in others we would expect a 1-to-several relationship; that is, the floristic heterogeneity characteristic of each ecological site should tend to be narrower than that of the broader ecological system, with species assemblages characterizing local landform and soil subunits (Fig. 4).

Additionally, as mentioned above, association concepts of the US-NVC may be used to characterize many of the floristic components of both ecological sites and the broader ecological system units (Kudray and Cooper 2005). In this way, these 3 approaches to ecological classification could be better integrated and likely strengthen the conceptual basis of each. These likely relationships could be effectively explored in areas, such as portions of the US Southwest, where both ecological systems concepts and ecological site concepts have been mapped, detailed floristic information has been gathered, and possible ambiguities induced by past land uses are not present.

However, we see a number of ambiguities introduced by the mapped expressions of these various classification concepts. Regional mapped hierarchies such as those provided by ECOMAP (Cleland et al. 2005) or NRCS land resource regions and major land resource areas (USDA, NRCS 2006) assist with an overall spatial organization for state-and-transition models, and in some instances, the mapped expression of ecological site types is determined by soil type polygons. Given the complexities and uncertainties of vegetation dynamics, they often fail to fully account for complex relationships of land features, disturbance, and vegetation patterns at more local scales. As a result, where ecological sites are depicted from the sole perspective of mapped land-based features (e.g., soil polygons), different ecological sites can sometimes be found to support identical suites of vegetative states, and at other times entirely 
different suites of vegetative states can be encountered with the same ecological site polygon.

Although much work is needed to further refine the descriptions and mapped expressions of ecological site concepts, an integration of ecological systems, ecological site descriptions, and the US National Vegetation Classification appears to be entirely feasible. Better integration among these various classification concepts should facilitate the costly multiagency efforts to gather, manage, and distribute data and strengthen each of these interrelated classification approaches.

\section{MANAGEMENT IMPLICATIONS}

For many years, the United States has lacked standard map products that bridge the thematic resolutions between national land cover data (e.g., with 10-20 natural land cover classes) and local mapping efforts (totaling several thousand classes if mapped comprehensively). Noss and Peters (1995), among many others, have long acknowledged the inadequacy of ecological data to effectively document status and trends for the nation's terrestrial ecosystems. Comprehensive maps of ecosystem types are also critical for assessment, priority setting, planning, and monitoring at ecoregional scales (Groves et al. 2002). What has been most lacking has been an appropriately structured and reasonably comprehensive mesoscale terrestrial ecological classification and the ancillary spatial data to allow for these concepts to be reliably mapped. Over the past decade, increasing availability of critical spatial data-and methods for mapping-has enabled the production of a national land cover map of much higher thematic resolution than was previously thought achievable.

The NatureServe classification of terrestrial ecological systems provides a practical, ecologically based classification standard for mapping natural land cover at regional or national scales where the intended applications are for natural resource management. The SWReGAP provided an important "proof of concept" that this level of thematic detail could be effectively mapped across some $20 \%$ of the coterminous United States with moderate to high spatial resolution. Establishing an a priori ecologically based classification and land cover legend for this 5-state region proved to be effective in coordinated efforts involving multiple mapping laboratories. But most important, because a standardized natural land cover classification was mapped, it can be used to answer cross-state questions for biodiversity conservation and resource management in the southwestern United States.

These classification concepts provide a direct, systematic link to the US-NVC and may be readily linked to finer-scale map units. Because terrestrial ecological systems are defined by integrating natural vegetation structure and composition with environmental settings and dynamic processes, they should provide a strong conceptual framework for state-and-transition models, with application to fire condition class assessment and ecological site description. With additional research, these classification concepts may form an effective bridge between ecological classification for national mapping and both vegetation and ecological site classification approaches more commonly applied at local scales.

\section{ACKNOWLEDGMENTS}

We wish to acknowledge the USGS BRD Gap Analysis Program for supporting this effort. Many of the concepts and approaches for defining and applying ecological systems have greatly benefited from collaborations with ecologists from numerous academic institutions, government agencies, and private organizations. We wish to express our sincere appreciation to ecologists from across the network of natural heritage programs that have contributed substantial expertise and ecological data to this effort. We especially thank the 5 SWReGAP state mapping teams for their collaborative efforts in applying ecological systems to land cover mapping in the southwestern United States. We greatly appreciate the helpful comments provided by John Lowry, Don Faber-Langendoen, Lisa Langs, Shannon Menard, and anonymous reviewers of this manuscript.

\section{LITERATURE CITED}

BAlley, R. G. 1996. Ecosystem geography. New York, NY: Springer-Verlag. 204 p. BAILEY, R. G. 1997. Ecoregions map of North America: explanatory note. Washington, DC: USDA Forest Service, Misc. Publication No. 1548. $10 p+$ map.

Barnes, B. V., D. R. Zak, S. R. Denton, and S. H. Spurr. 1998. Forest ecology. 4th ed. New York, NY: John Wiley and Sons. 774 p.

Bestelmeyer, B., J. E. Herrick, J. R. Brown, D. A. Trujlllo, and K. M. Havstad. 2004. Land management in the American southwest: a state-and-transition approach to ecosystem complexity. Environmental Management 1:38-51.

Bestelmeyer, B. T., D. A. Trujillo, A. J. Tugel, and K. M. Havstad. 2006. A multi-scale classification of vegetation dynamics in arid lands: what is the right scale for models, monitoring, and restoration? Journal of Arid Environments 65:296-318

BRINSon, M. M. 1993. A hydrogeomorphic classification for wetlands. Vicksburg, MS: Department of Defense, US Army Engineer Waterways Experiment Station, NTIS No. AD A270 053. Technical Report WRP-DE-4. $79 p+$ appendixes.

Briske, D. D., S. D. Funlendorf, and F. E. Smeins. 2005. State-and-transition models, thresholds, and rangeland health: a synthesis of ecological concepts and perspectives. Rangeland Ecology and Management 58:1-10.

Briske, D. D., S. D. Funlendorf, and F. E. Smeins. 2006. A unified framework for assessment and applications of ecological thresholds. Rangeland Ecology and Management 59:225-236.

Cleland, D. T., J. A. Freeguf, J. E. Keys, G. J. Nowacki, C. A. Carpenter, and W. H. McNAB. 2005. Ecological subregions: Sections and subsections for the conterminous United States. (A. M. Sloan, technical ed.). Washington, DC: US Department of Agriculture, Forest Service, Presentation scale 1:3,500,000; colored. Also available on CD-ROM consisting of GIS coverage in ArcINFO format.

Comer, P., D. Faber-Langendoen, R. Evans, S. Gawler, C. Josse, G. Kittel, S. Menard, M. Pyne, M. Reid, K. Schulz, K. Snow, and J. Teague. 2003. Ecological systems of the United States: a working classification of U.S. terrestrial systems. Arlington, VA: NatureServe. 75 p. Available at: http://www.natureserve.org/library/ usEcologicalsystems.pdf. Accessed 11 April 2007.

Cowardin, L. M., V. Carter, F. C. Golet, and E. T. LaRoe. 1979. Classification of wetlands and deepwater habitats of the United States. Washington, DC: US Fish and Wildlife Service, Biological Service Program, FWS/OBS-79/31. 103 p.

Delcourt, H. R., And P. A. Delcourt. 1988. Quaternary landscape ecology: relevant scales in space and time. Landscape Ecology 2:23-44.

Di Gregorio, A., And L. J. M Jansen. 2000. Land Cover Classification System (LCCS): classification concepts and user manual. Rome: Environment and Natural Resources Service, Africover-East Africa Project and Soil Resources, Management and Conservation Service, GCP/RAF/287/ITA. 179 p, 28 figures, 3 tables, including CD-ROM.

Drake, J., and D. Faber-Langendoen. 1997. An alliance level classification of the vegetation of the midwestern United States. Minneapolis, MN: The Nature 
Conservancy, Report to the University of Idaho Cooperative Fish and Wildlife Research Unit and National GAP Analysis Program. 397 p.

ECOMAP. 1993. National hierarchical framework of ecological units. Washington, DC: US Department of Agriculture, Forest Service, Unpublished administrative paper. $20 \mathrm{p}$. Ecoregions of the United States (map, revised ed.). Scale $1: 7500$ 000; colored.

Edwards, T. C., JR., C. H. Homer, S. D. Bassett, A. Falconer, R. D. Ramsey, and D. W. WIGHT. 1995. Utah gap analysis: an environmental information system. Logan, UT: Utah Cooperative Fish and Wildlife Research Unit, Utah State University, Final Project Report 95-1. $60 \mathrm{p}+$ appendixes.

Eve, M., And J. Merchant. 1998. A national survey of land cover mapping protocols used in the Gap Analysis Program. Final Report. Available at: http:// www.calmit.unl.edu/gapmap/report.html. Accessed 11 April 2007.

[FGDC] Federal Geographic Data Committee. 1997. Vegetation classification standard, FGDC-STD-005. 58 p. Available at: http://www.fgdc.gov/standards/ standards_publications/index_html. Accessed 11 April 2007.

Frost, C. C. 1998. Presettlement fire frequency regimes of the United States: a first approximation. In: T. L. Pruden and L. A. Brennan [EDs.]. Fire in ecosystem management: Shifting the paradigm from suppression to prescription. Tall Timbers Fire Ecology Conference Proceedings, No. 20. Tallahassee, FL: Tall Timbers Research Station. p 70-81.

Grossman, D. H., D. Faber-Langendoen, A. S. Weakley, M. Anderson, P. Bourgeron, R. Crawford, K. Goodin, S. Landahl, K. Metzler, K. D. Patterson, M. Pyne, M. Reid, AND L. SNeddon. 1998. International classification of ecological communities: Terrestrial vegetation of the United States. Volume I. The national vegetation classification system: Development, status, and applications. Arlington, VA: The Nature Conservancy. 126 p. Available at: http://www.natureserve.org/ library/vol1.pdf. Accessed 11 April 2007.

Groves, C. R., D. B. Jensen, L. L. Valutis, K. H. Redford, M. L. Shaffer, J. M. Scott, J. V. Baumgartner, J. V. Higgins, M. W. Beck, and M. G. Anderson. 2002. Planning for biodiversity conservation: putting conservation science into practice. Bioscience 52:499-512.

Herrick, J. E., B. T. Bestelmeyer, S. Archer, A. J. Tugel, and J. R. Brown. 2006. An integrated framework for science-based arid land management. Journal of Arid Environments 65:319-335.

Homer, C., C. Huang, L. Yang, L. B. Wylie, and M. Coan. 2004. Development of a 2001 national land cover database for the United States. Photogrammetric Engineering and Remote Sensing 70:829-840.

Jennings, M., O. Loucks, D. Glenn-Lewin, R. Peet, D. Faber-Langendoen, D. Grossman, A. Damman, M. Barbour, R. Pfister, M. Walker, S. Talbot, J. Walker, G. Hartshorn, G. Waggoner, M. Abrams, A. Hill, D. Roberts, and D. Tart. 2004. Guidelines for describing associations and alliances of the U.S. National Vegetation Classification. Washington, DC: The Ecological Society of America Vegetation Classification Panel. 142 p.

KuCHleR, A. W. 1988. Ecological vegetation maps and their interpretation. In: A. W. Kuchler and I. S. Zonneveld [EDS.]. Vegetation mapping. Boston, MA: Kluwer Academic Publishers. p 469-480.

Kudray, G., And S. Cooper. 2005. Linking the National Vegetation Classification System to ecological sites in southeastern Montana. Helena, MT: Montana Natural Heritage Program, Natural Resource Information System, Montana
State Library, Report to the Bureau of Land Management. 56 p. Available at: http://mtnhp.org/Reports/06_2005_X_Walk_Final.pdf. Accessed 11 April 2007.

Lowry John, H., JR., R. D. Ramsey, K. Boykin, D. Bradford, P. Comer, S. Falzarano, W. Kepner, J. Kirby, L. Langs, J. Prior-Magee, G. Manis, L. O’Brien, K. Pohs, W. Rieth, T. Sajwaj, S. Schrader, K. A. Thomas, D. Schrupp, K. Schulz, B. Thompson, C. Wallace, C. Velasquez, E. Waller, and B. Wolk. 2005. Southwest Regional Gap Analysis Project: final report on land cover mapping methods. Logan, UT: RS/GIS Laboratory, Utah State University. 50 p. Available at: http:// earth.gis.usu.edu/swgap/swregap_landcover_report.pdf. Accessed 11 April 2007.

McNab, W. H., And P. E. Avers [Comps]. 1994. Ecological subregions of the United States: section descriptions. Washington, DC: US Department of Agriculture, Forest Service. 267 p. Administrative Publication WO-WSA-5.

Mueller-Dombois, D., AND H. Ellenberg. 1974. Aims and methods of vegetation ecology. New York, NY: John Wiley and Sons. 547 p.

NatureServe. 2006. International classification of ecological communities: terrestrial vegetation of the United States. Arlington, VA: NatureServe. Available at: http://www.natureserve.org/explorer. Accessed 11 April 2007.

Noss, R. F., and R. L. Peters. 1995. Endangered ecosystems: a status report on America's vanishing habitat and wildlife. Washington, DC: Defenders of Wildlife. $67 \mathrm{p}$.

Olson, D. M., E. Dinerstein, E. D. Wikramanayake, N. D. Burgess, G. V. N. Powell, E. C. Underwood, J. A. D’Amico, I. Itoua, H. E. Strand, J. C. Morrison, C. J. Loukes, T. F. Allnutt, T. H. Ricketts, Y. Kura, J. F. Lamoreux, W. W. Wettengel, P. Hedao, AND K. R. KASSEM. 2001. Terrestrial ecoregions of the world: a new map of life on earth. Bioscience 11:933-938.

Reid, M. S., K. A. Schulz, P. J. Comer, M. R. Schindel, D. J. Culver, D. A. Sarr, and M. C. Damm. 1999. An alliance level classification of vegetation of the coterminous western United States. Boulder, CO: The Nature Conservancy. 1460 p. Report and CD to the Gap Analysis Program.

Rivas-Martinez, S. 1997. Syntaxonomical synopsis of the potential natural communities of North America. Itinera Geobotanica 10:5-148.

Sneddon, L., M. Anderson, and K. Metzler. 1994. A classification and description of terrestrial community alliances in The Nature Conservancy's Eastern Region: first approximation. Boston, MA: The Nature Conservancy, Eastern Heritage Task Force. 116 p. Unpublished report to USDI Fish and Wildlife Service, Gap Analysis Program.

Takhtajan, A. 1986. Floristic regions of the world. Transl. by T. J. Crovello and ed. by A. Cronquist. Berkley, CA: University of California Press. 522 p.

[USDA, nRCS] US Department of Agriculture, Natural Resources Conservation SERVICE. 2006. Land resource regions and major land resource areas of the United States, the Caribbean, and Pacific Basin. USDA Handbook 296. 663 p. Available at: http://soils.usda.gov/survey/geography/mlra/index.html. Accessed 11 April 2007.

Weakley, A. S., K. D. Patterson, S. Landaal, and M. Pyne [Comps]. 1998. International classification of ecological communities: terrestrial vegetation of the southeastern United States. Working draft of March 1998. Chapel Hill, NC: The Nature Conservancy, Southeast Regional Office, Southern Conservation Science Department, Community Ecology Group. 689 p.

West, N. E., F. L. Dougher, G. S. Manis, and R. D. Ramsey. 2005. A comprehensive land classification for Utah's West Desert. Western North American Naturalist 65:281-309. 